University of Wollongong

Research Online

Faculty of Law - Papers (Archive)

Faculty of Business and Law

$1-1-2012$

\title{
ASEAN and interconnecting regional spheres: lessons for the Indian Ocean Region
}

Shaun Lin

University of Wollongong, zs1957@uow.edu.au

Carl Grundy-Warr

National University of Singapore

Follow this and additional works at: https://ro.uow.edu.au/lawpapers

Part of the Law Commons

\section{Recommended Citation}

Lin, Shaun and Grundy-Warr, Carl: ASEAN and interconnecting regional spheres: lessons for the Indian Ocean Region 2012, 54-70.

https://ro.uow.edu.au/lawpapers/558

Research Online is the open access institutional repository for the University of Wollongong. For further information contact the UOW Library: research-pubs@uow.edu.au 


\title{
ASEAN and interconnecting regional spheres: lessons for the Indian Ocean Region
}

\begin{abstract}
In an era of shifting global geopolitical, geostrategic and geo-economic power, ASEAN's resilience as a regional grouping and its relative success in keeping internal conflicts at bay through various forms of quiet diplomacy and adherence to certain norms and binding principles mean that it may become a force helping to foster peaceful and stronger regional linkages within the eastern frontiers of the Indian Ocean Region (IOR). In this article we focus on ASEAN's growing roles and relations within three key 'spheres' of adjoining regional-extra-regional reach, which we identify as the mostly landward Greater Mekong Sphere (GMS), the South China Sea Sphere and the Bay of Bengal and Andaman Sea Sphere. The Bay of Bengal and Andaman Sea straddle between the Indian Ocean Region and ASEAN, so this offers a joint issue of cooperation and proximate regionalism. As for the GMS and South China Sea, the common Chinese factor holds important geo-economic and geopolitical references that IOR could incorporate into its foreign policy portfolio. Despite ASEAN's at times belowpar performances and contradictions in terms of regional and internal security, its direct and adjacent interconnectedness with the IOR suggests that it is perhaps one of the best institutions to learn from in terms of strengthening the IOR's future regionalism aspirations.
\end{abstract}

\section{Keywords}

asean, region, interconnecting, regional, spheres, lessons, indian, ocean

\section{Disciplines \\ Law}

\section{Publication Details}

Lin, S. \& Grundy-Warr, C. (2012). ASEAN and interconnecting regional spheres: lessons for the Indian Ocean Region. Journal of the Indian Ocean Region, 8 (1), 54-70. 


\title{
ASEAN and Interconnecting Regional Spheres: Lessons for Indian Ocean Region
}

\begin{abstract}
In an era of shifting global geopolitical, geostrategic and geo-economic power, ASEAN's resilience as a regional grouping and its relative success in keeping internal conflicts at bay through various forms of quiet diplomacy and adherence to certain norms and binding principles, mean that ASEAN may become a force helping to foster peaceful and stronger regional linkage within the eastern frontiers of the Indian Ocean Region (IOR). In this paper we focus on ASEAN's growing roles and relations within three key 'Spheres' of adjoining regional-extra-regional reach, in which we identified these as the mostly landward Greater Mekong Sphere, the South China Sea Sphere, and the Bay of Bengal and Andaman Sphere. The Bay of Bengal and Andaman Sea straddles between the Indian Ocean Region and ASEAN, so this offers a joint issue of cooperation and proximate regionalism. As for the GMS and South China Sea, the common Chinese factor holds important geo-economic and geopolitical references that IOR could incorporate in its foreign policy portfolio. Despite ASEAN's below par performances and contradictions in terms of regional and internal security at times, it's direct and adjacent interconnectedness with the IOR suggests it is perhaps one of the best institutions to learn from in strengthening IOR's future regionalism aspirations.
\end{abstract}

\section{Introduction}

In an era of shifting global geopolitical, geostrategic and geo-economic power, the Association of Southeast Asian Nations' (ASEAN) resilience as a regional grouping and its relative success in keeping internal conflicts at bay through various forms of quiet diplomacy and adherence to certain norms and binding principles, mean that ASEAN may become a force helping to foster peaceful and stronger regional linkage within the eastern frontiers of the Indian Ocean Region (IOR). Furthermore, ASEAN's significant geo-economic and geostrategic position contingent to other key regions 
benefitting from global power shifts (see Figure 1), mean that it is a vital part of the Indian Ocean Region's political, economic and security matrix. Finally, ASEAN's role as a long-established grouping with strategic partners through formats such as the ASEAN Regional Forum (ARF) since 1994 helps the regional body to play a vital role in developing dialogue and cooperative relations with major powers within and beyond the IOR. In this paper we shall focus upon ASEAN's growing roles and relations within three key 'Spheres' of adjoining regional-extra-regional reach. In Figure 1 we have identified these as the mostly landward Greater Mekong Sphere, the South China Sea Sphere, and the Bay of Bengal and Andaman Sphere. These spheres are the zones where ASEAN shares significant inter-state relations, inter-territoriality with neighbouring regions, with overlapping geo-economic, military-geostrategic, traditional and non-traditional security, environmental and human security interrelationships between neighbouring regions, states, also multiple public, private and civil society concerns.

$* * * * * * * * * * * * * * * * * * * * * * * * *$

Insert Figure 1 here

$* * * * * * * * * * * * * * * * * * * * * * * * *$

\section{IOR and ASEAN}

Since the end of the Cold War, and particularly in the last decade, global shifts that helped turn the IOR from being a relatively 'neglected' part of 'world geopolitics' and 'global geostrategy' into one that is very central, albeit with still a relatively high proportion of violent conflicts falling within the IOR as a whole (Bouchard and Crumplin 2010, p. 27). Significant global and regional geopolitical and economic structural adjustments are transforming the IOR into a dynamic global and regional security arena (Charurvedi 2009; Mohan 2011; Rumley and Chaturvedi 2004). Various shifts in political economic and geostrategic power are making the IOR one of the most dynamic inter-locking regions of the world, and the Indian Ocean Rim Association for Regional Cooperation (IOR-ARC) has become 'an extremely important regional grouping for the construction of a cooperative security 
region'(Research agendas for the Indian Ocean Region 2010). That said, the IOR should be considered 'as a complex puzzle of actors, each with their own vested interest or stakes, interacting in a multilayered time and space framework' (Bouchard and Crumplin 2010, p. 42). Keen observers have argued that the IOR-ARC has still failed to live up to expectations (Bateman and Chan 2011, p. 11). Beyond the IOR-ARC the Indian Ocean has a plethora or 'alphabet soup' (Bateman and Chan, 2011, p. 14) of intra- and sub-regional organizations such as the South Asian Association for Regional Cooperation (SAARC), none of them can address the multi-pronged issues of comprehensive security for the region as a whole, and there remains little 'tradition of collective security' (Mohan 2011, p. 21). All this suggests that there is a lack of resilience and coherence in terms of regionalization within the greater IOR. Thus, it may be constructive to consider what lessons may be derived from the ASEAN case that may enable peaceful coexistence and greater regional integrity within the IOR.

Why ASEAN? First, historically there were extremely strong ties across time and space in the IOR, which was for centuries a 'porous zone and passageway' for considerable mobility of people, ideas and goods, for pilgrimages and for cross-cultural linkage (Chew 2011; McPherson 1993; Wolters 1999). Second, it is clear that Southeast Asia is a crossroads and maritime space between South, Central, East Asia, Australia and the Pacific, and it also straddles the overlapping interests of India and China. Third, ASEAN has durability in terms of being a relatively peaceful regional association that was created in August 1967 at a time of enormous geopolitical and ideological schisms in the region, and raging war in Indochina. Fourth, ASEAN managed to expand to incorporate former foes and strangers (Vietnam, 1995; Laos, 1997; Myanmar, 1997; and Cambodia, 1999). All of which suggests that founding ASEAN principles, plus the Treaty of Amity and Cooperation (TAC) adopted by members in 1976, were flexible enough to help bring into the 'ASEAN Family', and accommodate, fundamentally different political states and political economies. Given the huge range of political states within the IOR the Southeast Asian example of 
regional association may hold valuable lessons for forging stronger linkages in spite of past crossborder conflicts and varying degrees of geopolitical paranoia. Finally, 'the ASEAN Way' holds promise for maintaining regional peace and security in other parts of the world (Goh 2003), albeit the specific historical circumstances and political cultural context cannot be so easily replicated outside of the region (Acharya 2001; Roberts 2012). Thus, it is worth considering some of the ASEAN norms, principles and mechanisms that may help to foster stronger political relations, functional and practical cooperation with the broader IOR (Emmers and Bateman 2011).

Some caution is required, for although the above points hold considerable promise for regional cooperation, ASEAN remains at best a nascent 'security community' (Acharya 2001), for it also characterized by multiple stubborn internal bilateral disputes, disparate political systems and varying degrees of democratization, and 'very little integration between the ASEAN states in the politicalsecurity sphere' (Roberts 2012: 184). That said, the low levels of complex integration are perhaps reasons for its durability and appeal in a region formerly divided by violence and warfare. Acharya (2001, p. 161) asked whether ASEAN's 'own norms' and 'way of life' were applicable to wider regional alignments in the Asia Pacific. In fact, ASEAN has been described by Rüland (2011, p. 103) as a 'norm entrepreneur' in terms of developing and disseminating ideas such as non-use of force, non-interference, progress by consultation and consensus, eschewing legalisms, and in spreading ASEAN principles via multilateral security forums, such as the ASEAN Regional Forum (ARF). According to Acharya (2001, p. 173): 'Through the ARF, ASEAN sought to create a regional order based not only on its norms, but also on the relatively new norm of inclusiveness, which is central to the idea of cooperative security.' Several aspects of the so-called 'ASEAN Way' crept into the ARF, including 'the cautious and incremental approach to security cooperation' (Acharya 2001, p. 174).

Central to the 'norm brewery' as Katsumata (2009, p. 5) puts it, is ASEAN's Treaty of Amity and Cooperation (TAC), including various 'informal codes of conduct' influencing regional interstate relations, such as respecting territorial sovereignty, national identity, national existence, non- 
interference in the internal affairs of one another, and the peaceful settlement of disputes (Emmers and Bateman 2011, p. 23). As Rüland (2011, p. 103) observes: 'ASEAN has acquired substantial prestige and credibility as a multilaterally minded actor, a fact that is corroborated by the accession of twenty-six countries' to the TAC. However, it is worthwhile citing Rüland (2011, p. 104) further:

The point is that ASEAN has indefatigably advocated these pacific norms in a region that forty years ago was by all standards one of the most conflict-prone in the world. What justifies the "brewery" analogy is the fact that ASEAN socialized them in the region by successfully framing them in local political culture. The political socialization theme has been discussed in detail elsewhere (Acharya 2000; 2001; 2009) in relation to the cultural politics of forging ASEAN norms and its regional identity. According to Leifer (1996) the ARF was viewed as a means to influence and socialize Beijing into good international behaviour, whilst helping to maintain Washington's security interests in the region. Emmers and Bateman (2011) suggest that the ARF is still 'ill-equipped' to tackle a host of security issues in the Asia Pacific, although it has helped to spread the security agenda to more comprehensive issues, including non-traditional areas such as maritime security, disaster relief, and humanitarian assistance.

In relation to the IOR region, it seems, that ASEAN's flexi-forms of cooperation may hold certain advantages in that ASEAN has a proven track-record as a productive norm maker and institution creator, yet it has done so in ways that require relatively little binding legislation, contractual relationships, and institutional costs to member states. ASEAN has relied greatly on forms of multilateralism that are more 'personalistic, informal and non-contractual' (Goh 2003, p. 115). Rüland (2011, p. 107) has theorized ASEAN as a 'hedging utility' that 'prefers a rather shallow multilateralism characterized by contingent, flexible, low-cost, thematically broad and only moderately accountable institutions.' Such a notion fits very well with ASEAN's stubborn 'sovereignty-centred' approaches to multilateral cooperation, whilst its 'norm brewery' keeps churning out a non-threatening palatable brew conducive to ASEAN, the ARF and likely most members of the IOR. The concept of 'hedging' also fits well with ASEAN's preference for 'soft' 
consensus-based approaches to disputes and disagreements, which may well help to smooth over some of the cracks and fissures created by bilateral tensions over space, boundaries and resources, of which there are many within the IOR. In the arena of maritime security, ASEAN's involvement alongside other IOR agents may help to foster 'a more cooperative mindset' which is lacking (Bateman 2011).

\section{Security dilemmas, threats and contradictions}

Hitherto, we have argued that ASEAN has proven to be relatively successful as a regional organization that has maintained mostly peaceful inter-state coexistence and developed forms of multilateral cooperation that have been highly suitable to the states in the region. It is also argued that ASEAN's political culture, guiding norms, and softer mechanisms may be highly appropriate in the greater IOR context. However, it is vital to highlight that ASEAN tends to support types of cooperation which are state-centred developmental and technocratic in nature, encouraging geoeconomic collaborations, investments (particularly by TNCs and FDI), trade, as well as encouraging economic globalization within and beyond the region through various initiatives (such as the Greater Mekong Sub-region or GMS, discussed below). ASEAN tends towards projects that forge cooperative ties without denting national sovereignties, whilst consensus is required to tackle any potential adverse externalities, particularly of the transnational kind.

When it comes to considerations of regional inter-governmental and inter-state security cooperation, traditional military and strategic concerns combine strongly with issues of economic and energy security (Berlin 2010; Rumley and Chaturvedi 2004; 2005). At the same time, cooperation over say matters of energy security may generate potential 'threats' and 'security dilemmas' (Rumley 2008). These dilemmas may be defined as 'the production of a security threatening situation for one state or region that arises as a result of the perceived consequences of another state's or region's behaviour in attempting to guarantee its own security' (also see Rumley 1999). There are security 
dilemmas that may arise from 'benign intent', 'uncertainty of intent', and 'paradoxical outcome' (Rumley 2008, p. 35). Actually, in each of the three frontiers Sphere zones of ASEAN (Figure 1) there are likely to be simultaneous and overlapping security dilemmas due to the large numbers of states involved, divergent geopolitical codes and imaginaries, and false perceptions of threats or even reasons for cooperation. Thus, we need to be cautious when applying the term 'cooperation' and 'security' because there are usually differentiated risks, benefits, and dilemmas are often present.

Until now, we have been totally preoccupied with regional inter-state cooperation and the possibility of ASEAN helping to foster more cohesive inter-regional links within the IOR. However, there are forms of security that necessitate thinking beyond national, state-centred and inter-state regional mindsets. In an Editorial setting out 'Research agendas' the notion of 'a multidimensional post-realist concept of security' incorporating ideas of environmental and human security was raised (Research agendas for the Indian Ocean Region 2010). Later the contributors go on to mention the need for 'more innovative interpretations' of the concept of 'environmental security' 'with the potential to secure access for all people to fulfil their basic needs for survival' (Ibid, p. 16). This raises a different form of security dilemma from that discussed above, for it may be that environmental, livelihood, food and other forms of human security are on the 'comprehensive security' agenda of regional organizations, but in practice come second or third place to other forms of security considered to be of higher priority.

An example is the extremely high priority often afforded to energy security, often without linkage to energy-related issues of environmental sustainability or the potential threats that may be created by accidental or unintended outcomes of energy resource exploitation. As Devare (2008, p. 34) argued 'the importance of energy in foreign policy calculations' is becoming extremely important in inter- and extra-regional relations. As we will illustrate, these forms of security are critical to understanding multiple developments, security threats and forms of cooperation in each of the three Spheres where ASEAN members have direct stakes. For every form of security there are often trade- 
offs and contradictions, particularly if in securing one resource, place or protecting some people another resource, place or people are made less secure. In the following sections, we shall particular aspects of energy, maritime and environmental geopolitics in relation to issues of regional development and ASEAN's role within those processes.

\section{Frontiers of ASEAN regional cooperation: geopolitical and geo-economic spheres of interest}

We suggest that lessons may be derived from closer examination of three broad maritime and land spheres that interconnect with the ASEAN membership territorial space. Like the broader IOR these spheres represent 'fuzzy and open' geo-economic and geopolitical systems (Bouchard and Crumplin, 2010: 42), and there are substantial trans-regional, transnational, and a whole plethora of traditional and non-traditional security interests at stake. Within each of three area Spheres (two essentially maritime dominated and one land-configured, see Figure 1), ASEAN member states and the regional body and various forums influenced or a part of ASEAN frameworks, are vitally involved. We argue that these connections involve overlapping political, economic and security interests that frequently place ASEAN in a position as facilitator and moderator in developing cross-regional and sub-regional forms of cooperation. Nevertheless, cross-sub-regional harmony continues to be complicated by obdurate national interests, boundary questions, stubborn sovereignty issues, and state rivalries within and across sub-regions.

\section{Sphere 1: ASEAN and the Greater Mekong Subregion}

The Mekong River does not just flow through six countries (China, Laos, Myanmar, Thailand, Cambodia and Vietnam) it is also a Basin that has spawned a new geo-economic regional imaginary of the Greater Mekong Subregion (GMS) advanced vigorously by the ADB, and essentially supported by ASEAN, discursively and materially moulding the six Mekong riparian nations into a so-named 'natural economic area. According to Hensengerth (2009, p. 338) 'the GMS is the product 
of the second wave of regionalism that swept through East and Southeast Asia after the Cold War' should be 'set in the context of post-Cold War efforts of nation-building and regional integration and the dual processes of globalization and regionalization.' In a critical examination of the GMS, Glassman (2010) conceptualizes the whole project as being an aspect of 'actually existing globalization' benefitting various large private and public sector concerns from distant GMS capitals and provincial centres, as well as transnational capitalist forces, which generate cross-regional linkages mostly for resource access, exploitation, and various 'scale-jumping' projects of accumulation (Glassman, 2010, p. 2).

The GMS Sphere and the ADB has had considerable support from ASEAN and ASEAN's mainland Southeast Asian governments. Projects include major east-west and north-south road corridors, various cross-border bridges, and the development of a regional energy grid, which has been increasingly based upon expanding hydropower within the Mekong Basin. In this section we shall focus primarily on just two issues: China - ASEAN relations in the Mekong, particularly in relation to China's unilateral development of a cascade of hydropower dams along the Lancang Jiang (China's portion of the Mekong River), and on hydropower developments to enhance energy security in the Lower Mekong Basin (LMB).

China has enormous exploitable hydropower resources, and many are found in mountainous western and south-western China. In a sense, China became a dragon of absolute sovereignty when she decided to go ahead with dam construction on the upper Mekong. To Beijing, such dams are viewed as necessary to help meet rising energy dams through the domestic supply of non-fossil fuel based energy, as well as to have enough energy to 'export' into mainland Southeast Asia's developing power grid (Yu 2003). Indeed, Chinese power companies are dominant players in the Southeast Asian hydropower industry (Middleton, Garcia and Foran 2009).

Upper mainstream dams have created much anxiety in downstream areas of the river, where there are fears of upstream control over water supplies by China. In this context, ASEAN has avoided 
confrontation with China over unilateral developments within Chinese national space, which is contrary to notions of territorial integrity and political sovereignty. Thus, ASEAN has at once been an active exponent of regionalization in the GMS, whilst side-stepping some of the more politically sensitive issues in relation to China. Indeed, China has played a very active part in the GMS project, which is part of the State-sponsored 'Go West' (for resources) as well as benefitting Chinese capital, some of whom are Sino hydropower companies. Downstream China has fully engaged with ASEAN neighbours in terms of aid and FDI, and has been an active partner in ASEAN's Mekong Basin Development program, based primarily on the regional energy grid and infrastructure projects. ASEAN is one of the organizations that have uncritically supported such forms of 'integration'.

One lesson from this is that mainland ASEAN States tend to espouse particular ideas of development based upon ADB-GMS geo-economic imaginaries, cooperation over hydropower supply, demand, and distribution networks, and energy security obsessions (Yong and Grundy-Warr forthcoming). Another lesson concerns ASEAN's acquiescence in relation to China's unilateral statecentred approach with potentially profound upstream-downstream consequences. This is not to say that ASEAN is toothless in relation to China, but rather dominant notions of GMS and a hydropowerdriven regional energy grid tend to obfuscate other important security issues, such as biodiversity, livelihoods, fisheries, food and environmental security (Molle, Foran and Käkönen 2009). As Goh (2004, p. 14) argues, the ASEAN states are less willing to address or to 'securitize' more ambiguous environmental security issues, which tend to be uneven, cumulative over time, abstract and unpredictable. Thus, ASEAN's effectiveness in regional security, and extra-regional relations, is often tempered by industry and issue-based alliances, as illustrated by the power grid and hydropower debates.

In the Mekong there are strong oppositional voices and networked alliances of civil society groups, community organizations, concerned professionals and scientists who do raise vital issues of environmental and human security. In recent years, there have been effective campaigns causing 
postponement of proposed lower Mekong mainstream dams, particularly at Don Sahong and Xayaburi in Laos PDR (Yong and Grundy-Warr forthcoming) There is much debate about the issue of mainstream hydropower dams on the mainstream of the lower Mekong River. The 1,260 megawatts Xayaburi Dam, located in Northern Lao, is the lower mainstream dam at the most advanced stage of planning. The US $\$ 3.5$ billion project is proposed by a predominantly Thai privatesector consortium, backed by Thai financiers, and would export 95\% of its electricity to Thailand. In September 2010, the Lao government initiated a regional decision-making process under the MRC called the "Procedures for Notification, Prior Consultation and Agreement" (PNPCA). The Xayaburi Dam and the PNPCA have been heavily contested; project proponents have argued for economic benefits and energy security, whilst opponents have pointed out environmental, social and cultural costs (Middleton, Grundy-Warr, and Yong 2012).

Environmental politics includes numerous trans-border alliances. Within ASEAN, regional history, norms and founding principles have shaped diverse interests both within and outside of the official PNPCA decision-making process. For example, each country has strongly defended their respective 'national interests', as represented by governments within the PNPCA process, and a country such as Lao PDR is insisting on its rights to go ahead with Xayaburi partly on grounds of sovereignty. A big factor in shaping regional politics is ASEAN's principle of political 'noninterference', counter-balancing commitments to cooperation through the Mekong River Commission. It is also the case that the Xayaburi Dam's Thai private-sector consortium has built nexuses with Lao and Thai state agencies to facilitate the project, and a trans-national private-sector is able to operate with flexibility beyond the 'national interest' and notions of political 'noninterference,' and beneath the scrutiny of civil society, with implications for region-wide water governance and environmental justice (Middleton 2012). Thus, ASEAN norms and values may not necessarily be conducive to developing regional environmental security within the IOR. 
At the regional and national scales, regional energy and economic integration are paramount in the security calculus above multiple less easily quantified calculations about adverse transnational externalities and long-term environmental effects. Thus, ASEAN's role is primarily to foster nonconfrontational geo-economic ties with China, whilst remaining mostly uncritical at the Association level of China's unilateral development of a trans-boundary resource. ASEAN's influence on the Mekong system is primarily in supporting on-going GMS projects, supporting a more efficient regional energy grid to emerge, whilst remaining aloof from the non-governmental and network alliances opposed to particular hydropower developments.

What the foregoing analysis suggests is that ASEAN and regional norms may well be exportable to the wider IOR, but the complex and critical issues of energy, environmental and human security throw up numerous problems that require thinking at multiple scales, beyond national sovereignty interests, and involve participation of numerous non-state parties. Whilst the ASEAN framework is indeed helpful for fostering certain types of economic linkage, there are numerous transnational challenges at sub-regional and cross-regional levels that may require alternative mechanisms and processes to state-centred regional ones. Mekong hydropolitics reveals certain limitations to the 'ASEAN model' requiring more critical analysis.

\section{Sphere 2: ASEAN and South China Sea}

In the maritime arena, the Indian Ocean has been described and argued as an imperative centre stage for energy geopolitics, a place that cannot be overlooked in the world geopolitics and global strategy (Berlin 2002; Cordner 2010; Kaplan 2009; Bouchard and Crumplin 2010). This is a largely valid statement considering how many countries in the world have their oil imports transported via this oceanic space. However, the Indian Ocean lacks a distinctive regional identity linked to a political association. Having said this, we examine another maritime space, the South China Sea, which sees ASEAN as an active regional player. In particular, we will reflect how ASEAN's involvement in the 
'troubled' South China Sea lends itself as a useful learning experience for South Asian countries seeking a cohesive regional order in the Indian Ocean. The relevance for this regionalism crossreference is not just because of proximity over at the eastern frontier of Indian Ocean, but also how these two salt water bodies share a common issue in dealing with Chinese interests.

Over the recent decades, the South China Sea has developed into a hotly disputed area between ASEAN and China. The main contentious issue at hand are the Spratly Islands and Paracel Islands territorial disputes. While the Paracel Islands involve only China and Vietnam, the Spratly Islands see China, Vietnam, Malaysia, Philippines and Brunei claiming all or some of the offshore features.All of them with the exception of Brunei exercise their territoriality by occupying and garrisoning specific islets. These tiny specks of islands and rocks spur nationalist fervour because of sovereignty at stake and attract greater interest due to the perception on the part of governments with regards to promises of resources in the surrounding waters and vital economic interests (Schofield 2011). Clashes out at sea are thus not surprising. Non-claimant states of the South China Sea within ASEAN (such as Singapore and Indonesia) are also monitoring the situation closely as they seek freedom of navigation and a peaceful marine environment in Southeast Asia. An attempt to reduce tensions in the region was signalled by ASEAN and China signing the Declaration on the Conduct of the Parties (DoC) in the South China Sea in 2002. A decade has since passed and yet tensions and conflicts still persist. Ian Storey, in an interview, attributes it to faults on both sides: China has obstructed the process, but there are also divisions withinASEAN as to the best way to proceed (Cook 2011).

Although the DoC is of limited success and the South China Sea remains a thorny problem within ASEAN and beyond the organisation with China, there is still much for the Indian Ocean Region (especially for those South Asian nations) to learn from ASEAN's regionalism approach. There are two reasons for it. First, ASEAN has a relatively good record of contributing to conflict avoidance and management in its own backyard (Emmers and Bateman 2011). Within the maritime ambit, the clashes between Southeast Asian countries never escalated into a regional crisis for 
ASEAN. In the highly contested South China Sea, the non-claimant states of the South China Sea and along with ASEAN as a group, does not support or oppose the claims of the four ASEAN claimant states, and has always urged peaceful talks to ease the tensions. ASEAN as a regional organisation has a fairly good record in shaping collective security measures within Southeast Asia. The collective defence diplomacy effort comes in formal and informal ministerial levels as well, such as the ASEAN Defence Ministers' Meeting (ADMM) (formal), to the ASEAN Chief of Defence Forces Informal Meeting (ACDFIM) and Shangri-La Dialogue and is initiated by both ASEAN as well as extra-regional powers such as China, Japan and the United States (Laksmana 2011). Therefore, ASEAN has an applicable lesson for the Indian Ocean Region to reflect upon, considering how countries like India and Bangladesh have an enduring maritime dispute over their Exclusive Economic Zones (EEZ). This is not to make an indirect claim that India and Bangladesh resort to military approaches to resolve their differences, but we wish to highlight how a political body like ASEAN could give ideas to the Indian Ocean Region in terms of having a regional organisation capable of managing bilateral and even multilateral maritime disputes in a diplomatic manner.

The second explanation is more crucial to illuminate the learning curves that the Indian Ocean Region could acquire in ASEAN's regionalism efforts. As mentioned earlier, the Chinese presence in both sea spaces gives a similar scenario for the Indian Ocean littoral states to study ASEAN's context of engaging China in the maritime domain. While it is a matter of territorial sovereignty and marine resources that justifies China's overtures in the South China Sea, it is another equation of geopolitics and geo-economics that vindicates China's venture into the Indian Ocean. As noted by Holmes and Yoshihara (2008, p. 369), the insatiable appetite for energy resources has brought tremendous domestic pressure on Beijing to assure an uninterrupted flow of energy, which compelled Beijing to cast anxious eyes on the sea lines of communication (SLOCs) in the Indian Ocean. This translates into a foreign policy of building port facilities at Sri Lanka (Hambantota) and Pakistan (Gwadar), creating a "string of pearls" that could eventually undermine India's pre-eminence (Berlin 2010; 
Holmes and Yoshihara 2008). Indeed, China's foray into the Indian Ocean cannot be underestimated. It could potentially reshape the political land and seascapes of the Indian sub-continent, where the Chinese invested ports encircle India.

India's responses to the "string of pearls" are not surprising. India has plans to construct a transhipment port at South Bay on Great Nicobar Island to counter Hambantota (Velloor 2010), and has been steadily increasing its military forays near the South China Sea by conducting naval exercises with Vietnam (a traditional "foe" with China) (Garver 2002; Khurana 2008). This individual effort by India may not be the best way to tackle the Chinese presence and even may distant herself from the rest of her South Asian neighbours. A better method would be turning to regionalism for security and political stability, such as getting the United States (US), a countering balance factor, to be more involved eastwards in the Indian Ocean rather than just dealing with piracy off the Horn of Africa. Since the regionalism of the Indian Ocean Region is primarily economic (Research agendas for the Indian Ocean Region 2010), referring to ASEAN for political and strategic regionalism directions is highly relevant.

ASEAN's extra regionalism reach is not solely being a diplomatic player of some relevance in Asia Pacific. Notably, it is capable of getting the US committed continuously to the security seascape of the South China Sea, such as offering its ports to the American warships and conducting joint military exercises to act as a counterweight to China. The need to straddle both Washington and Beijing's interests is seen in Ambassador-at-Large Professor Tommy Koh's recent interview, where he explained the ASEAN strategy as "[bringing] the major powers (particularly the US and China) together and embed them in a cooperative framework...thereby [reducing] the deficit of trust" (cited in Ho 2012, p. 2). This is also important in the context of South China Sea, as the People's Liberation Army Navy is clearly better equipped than Southeast Asian navies. Similarly, in relation to the Indian Ocean, a US presence may help balance the increasing Chinese capital ventures of seaports, and prevent a further divide between India and her neighbours. Regionalism in this sense will be more 
fruitful and countries such as Sri Lanka could welcome another source of foreign investment and engagement from the US to reduce its reliance on China. This is not to argue for skewing military and geostrategic security interests in favour of the US, but a recognition of big power interests and careful consideration of how to balance these geopolitical interests via regional forums and collective promotion of preventive diplomacy. Further, it may simply be that the relative decline of the US naval power in the region is chronic, for as Mohan (2011, p. 20) put it, 'the overall size of the US Navy is on the decline and the costs of deployment in the Pacific and Indian Ocean can only rise.' Nevertheless, ASEAN's vision and practice of having not just one superpower in its maritime territory is a worthy lesson to be learnt for the Indian Ocean Region, and one increasingly seen with the Indian naval engagements with various external powers, including the navies of US, France, Britain and Russia, as well as regional powers, including Australia. If the Indian Ocean Region wants to strive for effective regionalism, it is not merely an internal concern of having a common identity, but more importantly it is a question of having a right equilibrium of foreign interests, something which ASEAN manages relatively well.

\section{Sphere 3: ASEAN, Bay of Bengal and Andaman Sea}

There are several reasons why this sphere represents a complex and important geostrategic, geopolitical and geo-economic sphere implicating ASEAN with other IOR countries in profound ways. As Figure 2 illustrates the Bay is a trans-South-Southeast Asia maritime zone linking India, Sri Lanka and Bangladesh to the IOR ASEAN countries of Myanmar, Thailand and Malaysia. Each state may likely have their own complex array of geopolitical imaginaries of the sea-space, which may generate security dilemmas if policies or unilateral actions generate trans-border externalities. Further, there has historically been intense naval and maritime rivalry between India and China (Ahmad 2008; Mehta 2007; Mohan 2011). As a semi-enclosed $\mathrm{sea}^{1}$, meaning that much of the waters lie within the territorial seas and $200 \mathrm{~nm}$ EEZs of the littoral states, there are issues of overlapping 
claims, contested extended continental shelf submissions to the UN's Commission on the Limits of the Continental Shelf (CLCS), as well as problems for maritime boundary delimitation (Bateman 2010; Bissinger 2010). Thus, Bateman (2010) dubbed the Bay 'a new sea of troubles' and Bissinger discussed the need for states such as Bangladesh and Myanmar to attempt to settle their boundary dispute through negotiations and the International Tribunal for the Law of the Sea (ITLOS). Add to this troubled sea considerable gas finds and highly complex energy geopolitics (Basrur 2011; Devare 2008; Lall 2009) and it is clear that the Bay of Bengal offers numerous interrelated security challenges at the inter-state, intra-South, intra-Southeast Asia, and essential inter-regional levels. Each state in the Bay faces a challenging array of security issues, but numerous issues overspill national borders, which makes the building of collective security within the Bay area an urgent problem.

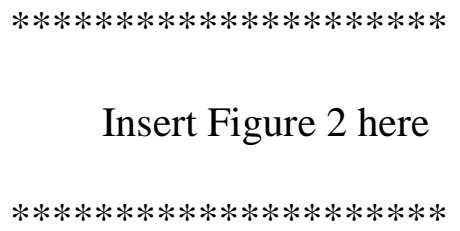

In many respects Myanmar has become a focal point in discussions about sub-regional IOR security. Essentially, Myanmar as an ASEAN member is in a front-line inter-regional position, caught not only between South and Southeast Asia, but also Central and East Asia in the northern borderlands. It is not wonder that the northern frontier with India and China was incorporated into van Schendel's notion of a mountainous "Zomia” which challenges dominant notions of area studies and nation-centred scholarly thinking (van Schendel 2005). Nevertheless, exactly similar arguments can be made for the sea-space of the Bay of Bengal in that by geopolitically divisions and purely national claims to space make a nonsense of historical flows, interactions, mobility and interaction spanning centuries (Chew 2011). 
Quite apart from the Bay of Bengal, Myanmar as a political state with a dominant and often repressive military regime has long represented a security conundrum for neighbouring states, particularly since the country's membership of ASEAN in 1997. Indeed ASEAN states have often had distinct views on how to deal effectively with Myanmar, involving differing interpretations of 'constructive engagement' (Bunyanunda 2002; Haacke 2008; Roberts 2006). Protracted conflict, complex ceasefires and ethnic politics within all the land border zones of the country have generated massive problems of human displacement and gross insecurity both within and across international borders for the last four decades (Callahan 2004; Grundy-Warr and Dean 2011; South, 2008; TBBC, 2012). Thus, discussing ASEAN's relative successes as a regional body with a peaceful record is not without significant caveats, particularly for the hundreds of thousands of Burmese exiles, irregular migrants, refugees and internally displaced persons who have often slipped out of the human security radar. Even as Myanmar has become less of an international 'pariah state' with the 'latest' release of Daw Aung San Suu Kyi and the authority's release of many political prisoners, there remain great uncertainties about the country's future internal politics and direction (Lintner 2012). Thus, Myanmar as a pivotal state in the practical geopolitics and geo-economics of at least three Asian regions represents a high order security conundrum, not just for ASEAN but for the IOR.

Undoubtedly within the Bay of Bengal area, resource and energy geopolitics have become paramount concerns of states. Much of the focus is on Myanmar's offshore oil and natural gas deposits, several blocks in the Gulf of Martaban (Yadana and Yetagun) being opened in the 1990s. ${ }^{2}$ This has only served to intensify Sino-Indian and Indian-Bangladesh rivalry and cooperation for precious energy resources (Basrur 2011; Islam 2009). The geostrategic and economic significance of resources in the Gulf have served to increase China's presence in attempting to secure gas deals and develop pipelines from the Bay of Bengal across Myanmar to Yunnan, Southwest China. Whilst India's 'Look East' policy (Lall 2008) has partly been geared towards developing better trade relations with ASEAN partners, partly to counter China's strong presence in mainland Southeast 
Asia, military and economic ties with Myanmar. The history of Sino-Indian rivalry in the IOR is long, and it is Myanmar that has been about 'to play its gas cards profitably' (Basrur 2011). One illustration of this was in the Shwe field off the Rakhine coast, blocks A1 to A3 being exploited by a consortium led South Korean's DaeWoo (60 per cent), the Korea Gas Corporation (10 per cent), and two Indian companies (ONGC Videsh, a subsidiary of Oil and Gas Corporation, 20 per cent, and GAIL, the Gas Authority of India, 10 per cent). In spite of the proximity of the gas fields to India, the Myanmar authorities were able to turn to China when tri-national negotiations in 2005 between Myanmar, India and Bangladesh stalled due to the latter country adding conditions to natural gas output going across her territory. This enabled PetroChina to sign a gas export MOU and complete survey work on a 2,389 $\mathrm{km}$ pipeline from Kyahphu in Myanmar to Yunnan Province. 'India was caught unaware when Myanmar had agreed to sell ... gas from Block-1 to PetroChina over 30 years' (Sinha 2009). Subsequently, the pipeline deal through Bangladesh was approved and India has secured further concessions from Myanmar for gas (BBC, 02 March 2010; BBC 14 October 2011).

Greater engagement with ASEAN has also enabled India to improve bilateral ties with various bilateral economic ties with individual countries, including an ASEAN Free Trade Agreement (Strachan, Kang and Sinha 2009). Geostrategic economic ties are as significant as purely military forms of cooperation. In such a competitive arena where gas geopolitics and maritime security of oil and gas sea-trade routes are critical to the security of states within and beyond the IOR, ASEAN and the South Asian Association for Regional Cooperation (SAARC) can help to act as regional watchdogs to monitor and try to encourage regional energy cooperation agreements. Through ASEAN there is greater dialogue potential between rival parties and regional powers (Devare 2008). As noted in the GMS, there is an intense focus on 'energy security' almost to the exclusion of other pressing non-traditional and transnational security concerns. As there is likely to be major investment and change in several coastal areas of the Bay of Bengal in the coming decade it is imperative that other issues, non-traditional security, environmental and human security are not left off the regional 
agenda. Bateman, Chan and Graham (2011) have provided a detailed list of pertinent ways that ASEAN may seek to enhance maritime security in the IOR both through formal agreements, institution-building, developing a host of cooperative arrangements in fields of maritime policing, information sharing, building upon existing regional bodies involved in tackling natural hazards, and various non-traditional security areas.

\section{Conclusion}

The IOR has already been elevated to global geopolitical attention. What it needs to address is building on its regionalism reach to maintain its relevance. ASEAN, a credible and highly pertinent organization east of the IOR, provides some valuable lessons. In our paper, we carefully examined the various lessons that IOR could 'import' from ASEAN. The Bay of Bengal and Andaman Sea straddles between the Indian Ocean Region and ASEAN, so this offers a joint issue of cooperation and proximate regionalism. As for the GMS and South China Sea, the common Chinese factor holds important geo-economic and geopolitical references that IOR could incorporate in its foreign policy portfolio. Despite ASEAN's below par performances and contradictions in terms of regional and internal security at times, it's direct and adjacent interconnectedness with the IOR suggests it is perhaps one of the best institutions to learn from in strengthening IOR's future regionalism aspirations. Finally, there are questions over the reliance on 'sovereignty-centred' forms of regional governance. As the discussion each of the Spheres suggests, there is a need to fundamentally address issues that go beyond ASEAN's current norms and practices. Indeed, whilst ASEAN's Charter encourages a "people-oriented" regional governance (Rüland 2011: 105), major decisions are either at state or inter-state level, which when dealing with complex issues of integrated ecology, natural resource management, resource-based livelihoods, river basins, coastal zones and seas, may raise problems and issues requiring more imaginative, multi-scalar and flexible forms of regional governance that is currently available. 
1 Under UNCLOS Part IX a semi-enclosed sea consists 'entirely or primarily of the territorial seas and exclusive economic zones of two or more coastal States.'

2 Myanmar's offshore area was divided into twenty-five blocks covering an area of 270,000 square kilometers. To the west of the Rakhine coast along the Bay of Bengal, there are seven blocks, A-1 to A-7. Eleven blocks (M-1 to M-11) were located in the Gulf of Martaban, in the northern sector of the Andaman Sea, and seven blocks (M-12 to M-18) were located by the Tanintharyi coastline, in the south, west of the Mergui Archipelago. See Ahmad (2008).

\section{Acknowledgments}

The authors would like to thank Lee Li Kheng for the preparation of the maps.

\section{References}

Acharya, A. (2000), The Quest for Identity: International Relations of Southeast Asia. Oxford: Oxford University Press.

Acharya, A. (2001), Constructing a Security Community in Southeast Asia: ASEAN and the Problem of Regional Order. London: Routledge.

Acharya, A. (2009), Constructing a Security Community in Southeast Asia. ASEAN and the Problem of Regional Order. $2^{\text {nd }}$ edition. London: Routledge.

Ahmad, T. (2008), 'Gas potential at the Bay of Bengal and implications for India's energy security', in S.T. Devare, ed., A New Energy Frontier. The Bay of Bengal Region. Singapore: Institute of Southeast Asian Studies, pp. 36-60.

Basrur, R. (2011), 'Energy and geopolitics in the Indian Ocean Region', in S. Bateman, J. Chan and E. Graham, eds., ASEAN and the Indian Ocean: The Key Maritime Links, RSIS Policy Paper, November 2011, Singapore: S. Rajaratnam School of International Studies, Nanyang Technological University, pp. 32-35. 
Bateman, S. (2010), 'Bay of Bengal: a new sea of troubles?', RSIS Commentaries 2010, no. 50, Nanyang Technological University.

Bateman, S. (2011), "Solving the "wicked problems" of maritime security: are regional forums up to the task?', Contemporary Southeast Asia: A Journal of International and Strategic Affairs, Vol. 33, no. 1, pp. 1-28.

Bateman, S. and Chan, J. (2011), 'Introduction', in S. Bateman, J. Chan and E. Graham, eds., ASEAN and the Indian Ocean: The Key Maritime Links, RSIS Policy Paper, November 2011, Singapore: S. Rajaratnam School of International Studies, Nanyang Technological University, pp. 7-14.

Bateman, S., Chan, J. and Graham, E. eds. (2011), 'ASEAN and the Indian Ocean: The Key Maritime Links', RSIS Policy Paper, November 2011, Singapore: S. Rajaratnam School of International Studies, Nanyang Technological University, pp. 7-14.

BBC (2010), 'Bangladesh approves India-Myanmar gas pipeline through its territory,' 2 March, 2010.

BBC (2011), 'India and Burma expand trade ties and sign gas deals,' 14 October, 2011, http://www.bbc.co.uk/news/world-south-asia-15304791 (accessed: 20 February 2012).

Berlin, D.L. (2002), 'Neglected no longer: strategic rivalry in the Indian Ocean', Harvard International Review, Vol. 24, no. 2, pp. 26-31.

Berlin, D.L. (2010), 'Sea power, land power and the Indian Ocean', Journal of the Indian Ocean Region, Vol. 6, no. 1, pp. 52-66.

Bissinger, J. (2010), 'The maritime boundary dispute between Bangladesh and Myanmar: motivations, potential solutions and implications', Asia Policy, no. 10, pp. 103-142. 
Bourchard, C. and Cumplin, W. (2010), 'Neglected no longer: the Indian Ocean at the forefront of world geopolitics and global geostrategy', Journal of the Indian Ocean Region, Vol. 6, no. 1, pp. 26-51.

Bunyanunda, M. (2002), 'Burma, ASEAN, and human rights: the decade of constructive engagement, 1991-2001', Stanford Journal of East Asian Affairs, Vol. 2, no. 1, pp. 118-135.

Callahan, M.P. (2004), Making Enemies: War and State Building in Burma. Ithaca, NY: Cornell University Press.

Chaturvedi, S. (2009), 'Indian Ocean', in R. Kitchen and N. Thrift, eds., International Encyclopedia of Human Geography. Oxford: Elsevier, Vol. 5, pp. 344-351.

Chew, E. (2011), 'Southeast Asia and the Indian Ocean: Maritime connections across time and space', in S. Bateman, J. Chan and E. Graham, eds., ASEAN and the Indian Ocean: The Key Maritime Links. RSIS Policy Paper, November 2011, Singapore: S. Rajaratnam School of International Studies, Nanyang Technological University, pp. 15-18.

Cook, T. (2011), 'Rising tensions in the South China Sea- An interview with Ian Storey', The National Bureau of Asian Research.

Cordner, L. (2010), 'Rethinking maritime security in the Indian Ocean Region', Journal of the Indian Ocean Region, Vol. 6, no. 1, pp. 67-85.

Devare, S.T. ed., (2008), A New Energy Frontier. The Bay of Bengal Region. Singapore: Institute of Southeast Asian Studies.

Emmers, R. and Bateman, S. (2011), 'ASEAN's model of conflict management', in S. Bateman, J. Chan and E. Graham, eds., ASEAN and the Indian Ocean: The Key Maritime Links, RSIS Policy Paper, November 2011, Singapore: S. Rajaratnam School of International Studies, Nanyang Technological University, pp. 24-27. 
Garver, J.W. (2002), 'The gestalt of Sino-India relationship', in C. Wilson Pumphrey, ed., The Rise of China in Asia: Security Implications. Carlisle, PA: Strategic Studies Institute, US Army War College, pp. 273-291.

Glassman, J. (2010), Bounding the Mekong: The Asian Development Bank, China, and Thailand. USA: University of Hawai'i Press.

Goh, E. (2004), 'China in the Mekong river basin: the regional security implications of resource development on the Lancang Jiang', Institute of Defence and Strategic Studies Working Paper, no. 69, Nanyang Technological University.

Goh, G. (2003), 'The 'ASEAN Way'. Non-intervention and ASEAN's role in conflict management', Stanford Journal of East Asian Affairs, Vol. 3, no. 1, pp. 113-118.

Grundy-Warr, C. and Dean, K. (2011), 'Not peace, not war: the myriad spaces of sovereignty, peace and conflict in Myanmar/Burma', in S. Kirsch and C. Flint, eds., Reconstructing Conflict: Integrating War and Post-War Geographies. Farnham and Burlington: Ashgate, pp. 91-114.

Haacke, J. (2008), 'ASEAN and political change in Myanmar: towards a regional initiative?', Contemporary Southeast Asia: A Journal of International and Strategic Affairs, Vol. 30, no. 3, pp. 351-378.

Hesengerth, O. (2009), 'Transboundary river cooperation and the regional public good: the case of the Mekong river', Contemporary Southeast Asia: A Journal of International and Strategic Affairs, Vol 31, no. 2, pp. 326-49.

Ho, B. (2011), 'ASEAN centrality: year of big power transitions', RSIS Commentaries 2012, no. 28, Nanyang Technological University.

Holmes, J.R. and Yoshihara, T. (2008), 'China's naval ambition in the Indian Ocean', Journal of Strategic Studies, Vol. 31, no. 3, pp. 367-394. 
Islam, M.S. (2009), 'Energy cooperation between India and Bangladesh: Economics and geopolitics,' in M. Lall ed., The Geopolitics of Energy in South Asia, Singapore: Institute of South Asian Studies and Institute of Southeast Asian Studies, pp.123-151.

Kaplan, R.D. (2009), 'Centre stage for the twenty-first century', Foreign Affairs, Vol. 88, no. 2, pp. 16-32.

Kasutama, H. (2009), 'ASEAN and human rights: resisting Western pressure or emulating the West?, The Pacific Review, Vol. 22, no. 5, pp. 619-637.

Khurana, G.S. (2008), 'China-India maritime rivalry', Indian Defence Review, Vol. 23, no. 4, pp. 1-6.

Laksmana, E.A. (2011), 'Defence diplomacy in Southeast Asia: trends, prospects and challenges', in B. Singh and S.S Tan, eds., From 'Boots' to 'Brogues': The Rise of Defence Diplomacy in Southeast Asia. RSIS/IDSS Monograph Series, pp. 71-89.

Lall, M. (2008), 'India-Myanmar relations - geopolitics and energy in the light of the new balance of power in Asia', Singapore: Institute of South Asian Studies Working Paper no. 29, National University of Singapore.

Lall, M. ed., (2009), The Geopolitics of Energy in South Asia. Singapore: Institute of Southeast Asian Studies.

Leifer, M. (1996), The ASEAN Regional Forum. Oxford: Oxford University Press.

Mohan, C.R. (2011), 'Contemporary strategic environment of the Indian Ocean Region: An overview', in S. Bateman, J. Chan and E. Graham, eds., ASEAN and the Indian Ocean: The Key Maritime Links, RSIS Policy Paper, November 2011, Singapore: S. Rajaratnam School of International Studies, Nanyang Technological University, pp. 19 -23.

Mcpherson, K. (1993), The Indian Ocean: A History of People and the Sea. New Delhi: South Asian Publishers. 
Mehta, S. Admiral (2007), Freedom to Use the Seas: India's Maritime Military Security, New Delhi: Integrated Headquarters, Ministry of Defence (Navy).

Middleton, C. (forthcoming), 'Thai foreign direct investment in the Xayaburi Dam in Lao PDR and its implications for human security and international cooperation', Asian Survey, accepted.

Middleton, C., Garcia, J. and Foran, T. (2009), 'Old and new hydropower players in the Mekong region: agendas and strategies', in F. Molle, T. Foran and M. Käkören, eds., Contested Waterscapes in the Mekong Region: Hydropower, Livelihoods and Governance. United Kingdom: Earthscan, pp. 23-45.

Middleton, C., Grundy-Warr, C. and Yong, M. (2012) 'Carving up the Commons: The hydropolitics of mainstream dams on the Mekong River', presented talk Environmental Cluster, National University of Singapore, 08 March 2012.

Molle, F., Foran, T. and Käkören, M. eds., (2009), Contested Waterscapes in the Mekong Region: Hydropower, Livelihoods and Governance. United Kingdom: Earthscan.

Roberts, C.B. (2006), 'Myanmar and the argument for engagement: a clash of contending moralities?', Institute of Defence and Strategic Studies Working Paper, no. 108, Nanyang Technological University.

Roberts, C.B. (2012), ASEAN Regionalism: Cooperation, Values and Institutionalization. London: Routledge.

Rumley, D. (1999), 'Geopolitical change and the Asia-pacific: the future of new regionalism' Geopolitics, Vol. 4, no. 1, pp. 83-97.

Rumley, D. (2008), 'Securitizing the Indian Ocean Region: concrete entity and geopolitical imaginations', in T. Doyle and M. Risely, eds., Crucible for Survival: Environmental Security 
and Justice in the Indian Ocean Region. New Brunswick, NJ: Rutgers University Press, pp. $25-43$.

Rumley, D. and Chaturvedi, S. eds., (2004), Geopolitical Orientations, Regionalism and Security in the Indian Ocean. New Delhi: South Asian Publishers.

Rumley, D. and Chaturvedi, S. eds., (2005), Energy Security and the Indian Ocean Region. New Delhi: South Asian Publishers.

Rüland, J. (2011), 'Southeast Asian regionalism and global governance: "Multilateral utility" or “hedging utility”?' Contemporary Southeast Asia: A Journal of International and Strategic Affairs, Vol. 33, no. 1, pp. 83-112.

Schofield, C. (2011), 'The delimitation of maritime boundaries: an incomplete mosaic', in D. Wastl-Walter, ed., The Ashgate Research Companion to Border Studies. Farnham and Burlington: Ashgate, pp. 665-681.

Sinha, T. (2009), 'China-Myanmar energy engagements: challenges and opportunities for India', Institute of Peace and Conflict Studies Issue Brief, no. 134, New Delhi: Southeast Asia Research Programme (SEARP).

South, A. (2008), Ethnic Politics in Burma: States of Conflict. London: Routledge.

Strachan, A.L., Kang, K.K., and Sinha, T. (2009), 'India's look East policy: a critical assessment. Interview with Ambassador Rajiv Sikri', New Delhi: Southeast Asian Research Programme, Institute of Peace and Conflict Studies.

van Schendel, W. (2005), 'Geographies of knowing, geographies of ignorance: jumping scale in Southeast Asia,' in P.H. Kratoska, R. Raben, and H.S. Nordholt, eds., Locating Southeast Asia: Geographies of Knowledge and Politics of Space. Singapore: Singapore University Press, pp. 275-308.

Velloor, R. (2010), 'Next big port of call: Nicobar', The Straits Times, 8 September. 
Wolters, O.W. (1999), History, Culture and Region in Southeast Asian Perspectives. Revised edition, Singapore: Institute of Southeast Asian Studies.

Yong, M.L. and Grundy-Warr, C. (forthcoming), 'Tangled nets of discourse and turbines of development: Lower Mekong mainstream dam debates', Third World Quarterly, accepted.

Yu, X. (2003), 'Regional cooperation and energy development in the Greater Mekong Subregion', Energy Policy, Vol. 31, no. 12, pp. 1221-1234.

(2010), 'Research agendas for the Indian Ocean Region', Journal of the Indian Ocean Region, Vol. 6, no. 1, pp. 1-25. 